\title{
Using stable isotopes to determine seasonal variations in water uptake of summer maize under different fertilization treatments
}

\author{
Ying Ma ${ }^{\mathrm{a}, \mathrm{b}, *}$, Xianfang Song ${ }^{\mathrm{a}}$ \\ ${ }^{a}$ Key Laboratory of Water Cycle and Related Land Surface Processes, Institute of Geographic Sciences and Natural Resources Research, Chinese Academy of Sciences, 100101 Beijing, China \\ b State Key Laboratory of Soil and Sustainable Agriculture, Institute of Soil Science, Chinese Academy of Sciences, 210008 Nanjing, China
}

\section{H I G H L I G H T S}

- Dual stable isotopes and MixSIAR were coupled to quantify water uptake of maize.

- Maize mainly used soil water in 20 $50 \mathrm{~cm}$ at milk stage and $0-20 \mathrm{~cm}$ at other stages.

- Fertilization treatments led to distinct water uptake pattern at $0-50 \mathrm{~cm}$ depth.

- Soil water contribution was significantly linear with proportion of root length.

\section{A R T I C L E I N F O}

\section{Article history:}

Received 2 October 2015

Received in revised form 21 January 2016

Accepted 22 January 2016

Available online 2 February 2016

Editor: F.M. Tack

\section{Keywords:}

Root water uptake

Dual stable isotopes

MixSIAR model

Fertilization

Summer maize

\section{GRA P H I C A L A B S T R A C T}

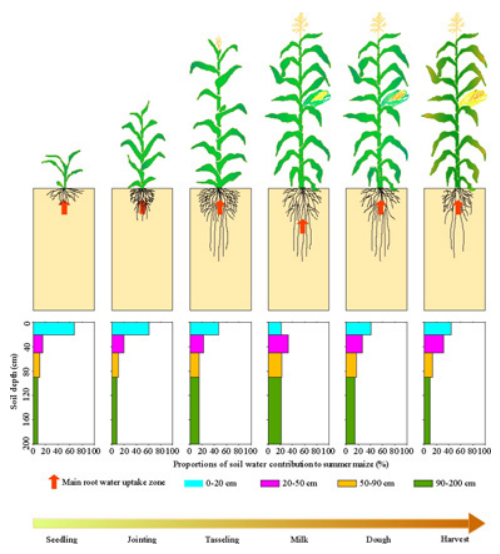

\section{A B S T R A C T}

Fertilization and water both affect root water uptake in the nutrient and water cycle of the Soil-PlantAtmosphere-Continuum (SPAC). In this study, dual stable isotopes ( $D$ and ${ }^{18} \mathrm{O}$ ) were used to determine seasonal variations in water uptake patterns of summer maize under different fertilization treatments in Beijing, China during 2013-2014. The contributions of soil water at different depths to water uptake were quantified by the MixSIAR Bayesian mixing model. Water uptake was mainly sourced from soil water in the $0-20 \mathrm{~cm}$ depth at the seeding (67.7\%), jointing (60.5\%), tasseling (47.5\%), dough (41.4\%), and harvest (43.9\%) stages, and the $20-50 \mathrm{~cm}$ depth at the milk stage (32.8\%). Different levels of fertilization application led to considerable differences in the proportional contribution of soil water at $0-20 \mathrm{~cm}(6.0-58.5 \%)$ and $20-50 \mathrm{~cm}(6.1-26.3 \%)$. There was little difference of contributions in the deep layers (50-200 cm) among treatments in 2013, whereas differences were observed in 50-90 $\mathrm{cm}$ at the milk stage and $50-200 \mathrm{~cm}$ at the dough stage during 2014 . The main water uptake depth was concentrated in the upper soil layers $(0-50 \mathrm{~cm})$ during the wet season (2013), whereas a seasonal drought in 2014 promoted the contribution of soil water in deep layers. The contribution of soil water was significantly and positively correlated with the proportions of root length $(r=0.753, p<0.01)$. The changes of soil water distribution were consistent with the seasonal variation in water uptake patterns. The present study identified water sources for summer maize under varying fertilization treatments and provided scientific implications for fertilization and irrigation management.

(c) 2016 Elsevier B.V. All rights reserved.

\footnotetext{
* Corresponding author at: Key Laboratory of Water Cycle and Related Land Surface Processes, Institute of Geographic Sciences and Natural Resources Research, Chinese Academy of Sciences, 100101 Beijing, China.

E-mail address: maying@igsnrr.ac.cn (Y. Ma).
} 


\section{Introduction}

Fertilization and irrigation can significantly affect field nutrient and water cycles (Tilman et al., 2002; Wang and Huang, 2008; Qi et al., 2011). Water cycling in the Soil-Plant-Atmosphere-Continuum (SPAC) is one of the foundations of water-saving agriculture. In recent decades, there has been increasing focus on the interactions among precipitation and soil, plant, atmospheric, and ground water (Philip, 1966; Liu, 1997; Kang et al., 2000; Wang et al., 2009; Zhang et al., 2011a). However, it is very difficult to quantify the water fluxes of evaporation, transpiration, and drainage through the SPAC interfaces, and estimating these fluxes is essential to improve crop water use efficiency. Root water uptake plays an important role in water interaction among the SPAC interfaces by indicating the crop's ability to use soil water resources and respond to changes in soil moisture distribution (Asbjornsen et al., 2007; Wang et al., 2010). Moreover, root water uptake provides critical insights into optimizing irrigation management practices.

Stable isotopes ( $\delta \mathrm{D}$ and $\delta^{18} \mathrm{O}$ ) have been widely used to study hydrologic cycles (Gat, 1996), ecological processes (Brunel et al., 1997), water quality evolution (Butler II, 2007), contaminant sources identification (Popescu et al., 2015), and palaeoclimates (Maduabuchi et al., 2006) across multiple temporal and spatial scales. The stable isotopes tracing technique provides an effective and unintrusive way to assess plant root water uptake patterns (Ehleringer and Dawson, 1992). Zimmermann et al. (1967) demonstrated that no fractionation of the isotopes occurred during water transfer from the soil to the plant. Therefore, comparison of the isotopic composition in the plants and possible sources of water can be used to infer the depth of water uptake (Brunel et al., 1995). The proportion of varying potential water sources accessed by plants was preliminarily determined using stable isotope analysis in conjunction with two- or three-compartment linear mixing models (Snyder and Williams, 2000; Darrouzet-Nardi et al., 2006; McCole and Stern, 2007). However, the linear mixing models were unable to provide a unique solution when the number of sources exceeded three. Based on the isotopic mass balance principle, Phillips and Gregg (2003) presented the IsoSource mixing model for determining the ranges of multiple source contributions. However, the IsoSource model did not incorporate the uncertainty of sources and could not give definite proportions of source contributions. Recently, the Bayesian mixing models (MixSIR, SIAR, SISUS, MixSIAR) have been developed explicitly to account for uncertainties in isotope values and the estimates of source contributions (Moore and Semmens, 2008; Ward et al., 2010; Parnell et al., 2010; Erhardt and Bedrick, 2013; Stock and Semmens, 2013), and have been widely used to quantitatively identify water sources used by woody plantations (Yang et al., 2015; Schwendenmann et al., 2015).

Stable isotopes have been increasingly applied to identify water sources used by crops (Asbjornsen et al., 2007; Wang et al., 2010; Zhang et al., 2011b). Asbjornsen et al. (2007) used the IsoSource model to assess the depth of water uptake in the soil horizon by contrasting annual (corn) and perennial ecosystems in central Iowa. Wang et al. (2010) applied the IsoSource model to estimate root water uptake patterns of summer corn and cotton in the shallow groundwater area of Shanxi Province, China. Zhang et al. (2011b) coupled a two-compartment liner mixing model with a $\delta \mathrm{D}-\delta^{18} \mathrm{O}$ plot to calculate the contribution of various water sources to maize during different growth stages, but the model required that the values of $\delta \mathrm{D}$ and $\delta^{18} \mathrm{O}$ of all sources have a significant linear correlation. In comparison, the Bayesian mixing models have advantages in quantifying contributions of water sources to crop with definite proportions and accounting for the uncertainty of water sources in SPAC. To our knowledge, the Bayesian mixing models have not been used to investigate the water uptake characteristics of crops. Furthermore, previous studies were limited to a single season and did not consider differences in seasonal water supply (precipitation or irrigation) and the impacts of fertilization on crop water uptake patterns. The MixSIAR Bayesian isotope mixing model incorporates advances in Bayesian mixing model theory since MixSIR (the original Bayesian mixing model, GUI in MATLAB) and SIAR (residual error, R package). It substantially accounts for the uncertainties in plant and source isotope values and allows for the input of multiple isotopes with raw source data, and addresses hierarchical random or fixed effects in analysis (Stock and Semmens, 2013).

In this study, the MixSIAR Bayesian mixing model together with D and ${ }^{18} \mathrm{O}$ dual stable isotopes technique was used to determine water uptake patterns of summer maize under different fertilization treatments during 2013-2014 in Beijing, China. This study had three primary objectives: (1) to quantify the contribution of soil water at different depths to water uptake by summer maize; (2) to compare the seasonal variations in maize water uptake patterns under different fertilization and precipitation conditions; (3) to evaluate the relationships between maize water uptake with root distribution and soil moisture. The results of this study are expected to provide implications for fertilization and irrigation management of summer maize.

\section{Materials and methods}

\subsection{Field experiments}

Field experiments with summer maize were conducted during 2013-2014 at the Irrigation Experiment Station of the China Institute of Water Resources and Hydropower Research (IWHR) at Daxing district, Beijing $\left(39^{\circ} 37^{\prime} \mathrm{N}, 116^{\circ} 26^{\prime} \mathrm{E}\right.$ and $40.1 \mathrm{~m}$ a.s.l.). The local climate is sub-humid, with mean annual precipitation of $540 \mathrm{~mm}$ and mean annual temperature of $12.1^{\circ} \mathrm{C}$ (Cai et al., 2009). The seasonal distribution of precipitation is uneven, with approximately $70 \%-80 \%$ of precipitation occurring during the summer maize season from June to September. The soil in the experimental area consists of sandy loam and silt loam in $2 \mathrm{~m}$ depth, which is formed by loess deposits. The main soil properties are presented in Table 1. The water table depth in the area is on average $16 \mathrm{~m}$ below the soil surface. The reference evapotranspiration $\left(\mathrm{ET}_{0}\right)$ was 387.5 and $372.6 \mathrm{~mm}$ in the 2013 and 2014 season, respectively, and the temporal variation of $\mathrm{ET}_{0}$ was shown in Fig. 1.

The summer maize, variety Lianke-96, was planted by late June and harvested in early October. There were five fertilization treatments with different nitrogen application rates $(0 \mathrm{~N}, 0.5 \mathrm{~N}, 0.75 \mathrm{~N}, 1.0 \mathrm{~N}$, and $1.5 \mathrm{~N})$. The $1.0 \mathrm{~N}$ treatment represented conventional practice with a total nitrogen application rate of $245 \mathrm{~kg} \mathrm{~N} \mathrm{ha}^{-1}$ (as urea). The nitrogen application rates of $0 \mathrm{~N}, 0.5 \mathrm{~N}, 0.75 \mathrm{~N}$, and $1.5 \mathrm{~N}$ treatments were $0-, 0.5-$, 0.75 -, and 1.5 -fold that of the $1.0 \mathrm{~N}$ treatment, respectively. Detailed fertilization events are presented in Table 2. Each treatment had three replicates with a corresponding plot area of $6 \times 5 \mathrm{~m}$. Precision leveled basins were used to prevent run-off. Summer maize was irrigated only when the monsoon rains were scarce in this area. The rainfall was $438.9 \mathrm{~mm}$ and $271.0 \mathrm{~mm}$ in the 2013 and 2014 experimental seasons, respectively (Fig. 1). No irrigation was applied in the 2013 season. Irrigation of $60 \mathrm{~mm}$ and $80 \mathrm{~mm}$ was applied on June 20th and August 30th, respectively, for all treatments in the 2014 season. All treatments were performed by basin irrigation with groundwater.

Soil water contents were measured every 5 to 7 days using the TRIME-IPH probe (IMKO GmbH, Ettlingen, German) at 20-cm intervals along the 2-m soil profile in each plot. Additional measurements were recorded before and after each irrigation or heavy rainfall event. The roots of the summer maize were sampled by a soil auger $(9.5 \mathrm{~cm}$ diameter) at harvest. Two soil cores in planting and intra-row locations were taken every $10 \mathrm{~cm}$ in the $1-\mathrm{m}$ profile for each treatment and the soil was removed manually in washing cans. Root length was analyzed by the WinRHIZO system (Regent Instruments, Quebec, Canada). Weather data, including daily precipitation, maximum and minimum air temperatures, solar radiation, average wind speed, and average relative humidity were measured using an automatic weather station (Monitor Sensors, Australia). 
Table 1

Physical and chemical properties of the soil at the experimental site.

\begin{tabular}{|c|c|c|c|c|c|c|c|c|c|c|c|c|}
\hline \multirow{2}{*}{$\begin{array}{l}\text { Depth } \\
(\mathrm{cm})\end{array}$} & \multicolumn{3}{|c|}{ Particle size (\%) } & \multirow{2}{*}{$\begin{array}{l}\text { Soil } \\
\text { texture }\end{array}$} & \multirow{2}{*}{$\begin{array}{l}\text { Bulk density } \\
\left(\mathrm{g} \mathrm{cm}^{-3}\right)\end{array}$} & \multirow{2}{*}{$\begin{array}{l}\theta_{\mathrm{s}} \\
\left(\mathrm{cm}^{3} \mathrm{~cm}^{-3}\right)\end{array}$} & \multirow{2}{*}{ 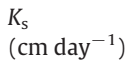 } & \multirow{2}{*}{$\begin{array}{l}\mathrm{OC} \\
\left(\mathrm{g} \mathrm{kg}^{-1}\right)\end{array}$} & \multirow{2}{*}{$\begin{array}{l}\text { EC } \\
\left(\mu \mathrm{Scm}^{-1}\right)\end{array}$} & \multirow[t]{2}{*}{$\mathrm{pH}$} & \multirow{2}{*}{$\begin{array}{l}\mathrm{NH}_{4}^{+}-\mathrm{N} \\
\left(\mathrm{mg} \mathrm{kg}^{-1}\right)\end{array}$} & \multirow{2}{*}{$\begin{array}{l}\mathrm{NO}_{3}^{-}-\mathrm{N} \\
\left(\mathrm{mg} \mathrm{kg}^{-1}\right)\end{array}$} \\
\hline & Sand & Silt & Clay & & & & & & & & & \\
\hline $0-20$ & 58.8 & 33.2 & 8.0 & Sandy loam & 1.56 & 0.41 & 8.41 & 7.73 & 113.50 & 8.30 & 3.14 & 24.26 \\
\hline $20-120$ & 65.3 & 26.7 & 8.0 & Sandy loam & 1.48 & 0.42 & 10.04 & 3.40 & 96.54 & 8.52 & 1.95 & 14.31 \\
\hline $120-180$ & 68.2 & 29.2 & 2.7 & Sandy loam & 1.45 & 0.45 & 7.45 & 1.86 & 117.70 & 8.64 & 0.79 & 8.79 \\
\hline $180-200$ & 32.0 & 51.0 & 17.0 & Silt loam & 1.25 & 0.51 & 0.66 & 5.47 & 178.70 & 8.58 & 1.99 & 14.74 \\
\hline
\end{tabular}

Note: OC: organic C; $\theta_{\mathrm{s}}$ : saturated water content, $K_{\mathrm{s}}$ : saturated hydraulic conductivity, EC: electric conductivity, $\mathrm{NH}_{4}^{+}-\mathrm{N}$ : ammonia nitrogen, $\mathrm{NO}_{3}^{-}-\mathrm{N}$ : nitrate nitrogen.

\subsection{Water sampling and isotope analyses}

During the experiments, precipitation, irrigation water, soil water, and stem water were sampled for hydrogen and oxygen stable isotopes analysis. A rain collector consisting of a polyethylene bottle and funnel was placed outside and a ping pong ball was positioned at the funnel mouth to prevent evaporation during rainfall (Wang et al., 2012). After each rainfall event, rainwater was collected and immediately transferred to a bottle and sealed and stored. Irrigation water samples were collected when crops were irrigated.

At the different growth stages of summer maize (seedling, jointing, tasseling, milk, dough, and harvest), soil water was sampled at depths of $10,20,30,50,70,90,110,150$, and $200 \mathrm{~cm}$, using a suction lysimeter which was composed of a Teflon pipe and porous ceramic cup (Wang et al., 2012). A vacuum of about $-0.8 \mathrm{MPa}$ was applied to the suction lysimeter for $12 \mathrm{~h}$ of equilibrium to collect soil water. If the soil was too dry to collect water at a certain depth, the soil was sampled with a hand-auger. Additional soil water was sampled after each irrigation or heavy rainfall event. In total, 15 and 13 times of soil water were sampled in the 2013 and 2014 season, respectively.

(a)

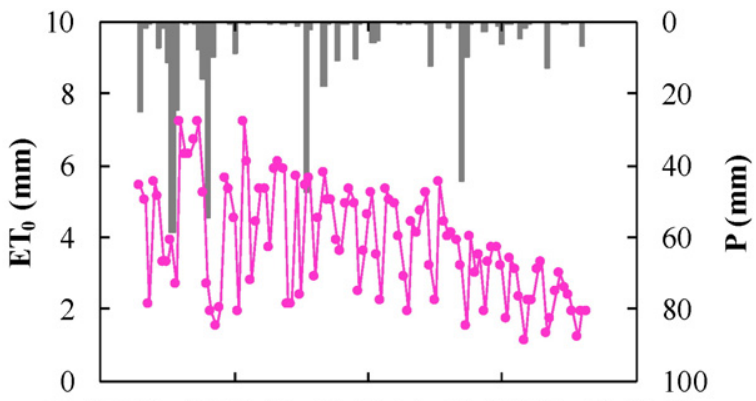

13-06-15 13-07-15 13-08-14 13-09-13 13-10-13

Date (yy-mm-dd)

(b)

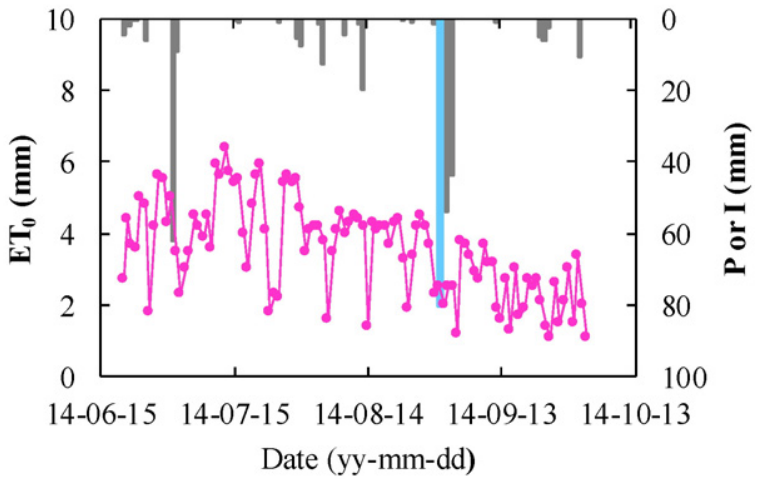

$\mathrm{P}=\mathrm{I} \longrightarrow \mathrm{ET}_{0}$

Fig. 1. Temporal variations of reference evapotranspiration $\left(\mathrm{ET}_{0}\right)$, precipitation $(\mathrm{P})$, and irrigation (I) in the: (a) 2013, and (b) 2014 season, respectively.
Three plants of summer maize were selected for stem sampling in each plot. Stem and soil water samples were taken on the same day. The selected stems were near the soil and below the first node. The epidermis of the stems was removed because it may have been in isotopic equilibrium with the isotopically depleted atmospheric water vapor (Brunel et al., 1997). Every stem was cut into pieces of 2-3 cm length pieces that were placed in a vial and sealed with parafilm.

All the soil and stem water samples were kept frozen in a freezer $\left(-15^{\circ} \mathrm{C}\right.$ to $\left.-20^{\circ} \mathrm{C}\right)$ before isotopic analysis. Water in the soil samples and crop stems was extracted using a cryogenic vacuum distillation system (LI-2000, LICA, China) (West et al., 2006). This process took $1.0-1.5 \mathrm{~h}$ depending on the water content of the samples. The extracting percent of water from the samples was over $98.0 \%$, which would be sufficient to obtain unfractionated water samples.

Isotopic measurements for the $\mathrm{D}$ and ${ }^{18} \mathrm{O}$ content were carried out using the off-axis integrated cavity output spectroscopy method (Model DLT-100, Los Gatos Research, America). All water samples were calibrated and normalized to internal laboratory water standards that were previously calibrated relative to the Vienna Standard Mean Ocean Water (VSMOW, $0 \%$ ). The results were expressed as $\delta$-values, which were relative to VSMOW on a normalized scale: $\delta(\%)=$ $\left(\mathrm{R}_{\text {sample }}-\mathrm{R}_{\text {standard }}\right) / \mathrm{R}_{\text {standard }} \times 1000$, where $\mathrm{R}$ referred to the ${ }^{18} \mathrm{O} /{ }^{16} \mathrm{O}$ or ${ }^{2} \mathrm{H} /{ }^{1} \mathrm{H}$ ratio. The measurement accuracy was consistently $\pm 1 \%$ for $\delta \mathrm{D}$ and $\pm 0.1 \%$ for $\delta^{18} \mathrm{O}$.

\subsection{The MixSIAR model}

The MixSIAR Bayesian isotope mixing model (v2.1.3) (Stock and Semmens, 2013) was used to identify sources of water used by summer maize. In this study, the potential source of water uptake by summer maize was considered to be soil water at different depths, which was mixed proportionally with old soil water, rainfall and irrigation. Groundwater was not considered one of the water resources for summer maize because of the deep water table depth (on average $16 \mathrm{~m}$ below the soil surface) in the study area. The mixing model sources were selected primarily on their isotopic composition and supported by soil moisture levels and root distribution. The top soil layer $(0-20 \mathrm{~cm})$ was distinguishable from the remainder of the profile as it was the most isotopically unstable zone. This instability reflected the evaporative fractionation of soil water that occurred during the dry season and the mixing processes that took place during infiltration of precipitation (Barnes and Turner, 1998). The isotopic composition in the

Table 2

Fertilization (as urea) schedule of each treatment. (unit: $\mathrm{kgN} \mathrm{ha}^{-1}$ ).

\begin{tabular}{llccllll}
\hline Treatment & Seedling & Jointing & Tasseling & milk & Dough & Harvest & Total \\
\hline $0 \mathrm{~N}$ & - & 0 & 0 & - & - & - & 0 \\
$0.5 \mathrm{~N}$ & - & 61.25 & 61.25 & - & - & - & 122.5 \\
$0.75 \mathrm{~N}$ & - & 91.875 & 91.875 & - & - & - & 183.75 \\
$1.0 \mathrm{~N}$ & - & 122.5 & 122.5 & - & - & - & 245 \\
$1.5 \mathrm{~N}$ & - & 183.75 & 183.75 & - & - & - & 367.5 \\
\hline
\end{tabular}

Note: The $1.0 \mathrm{~N}$ treatment represented conventional practice, and “-" shows no fertilization applied. 
2013

(a)

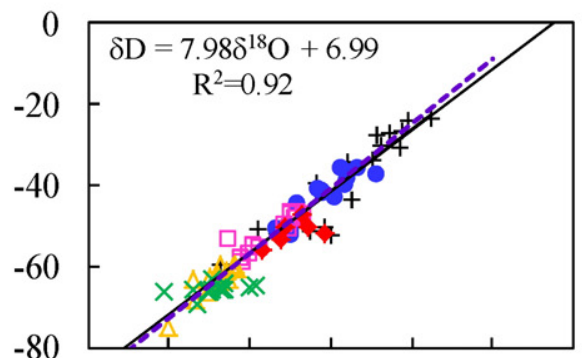

(b)

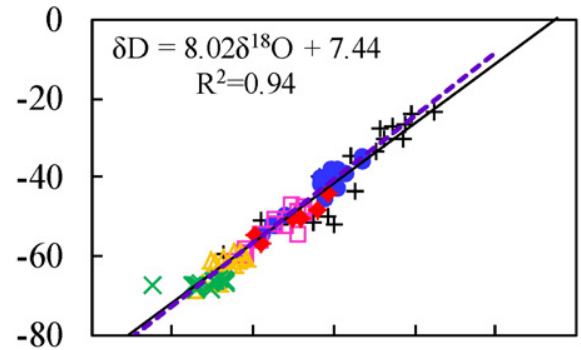

(c)

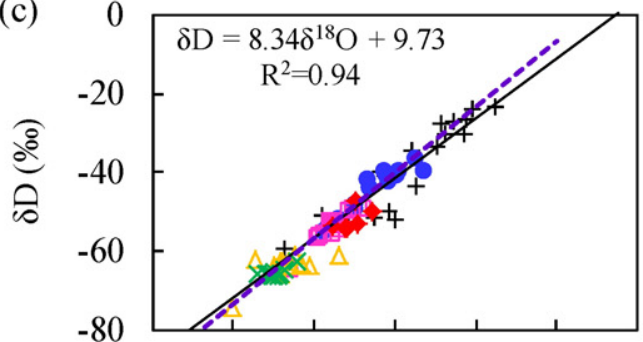

(d)

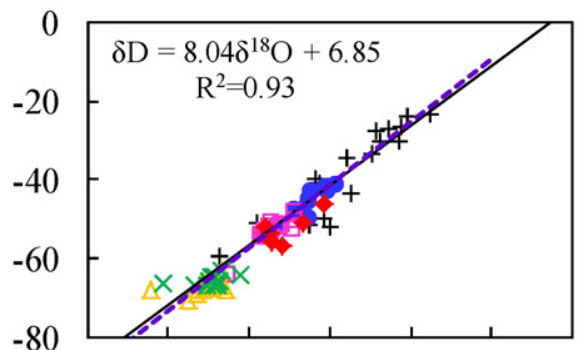

(e)

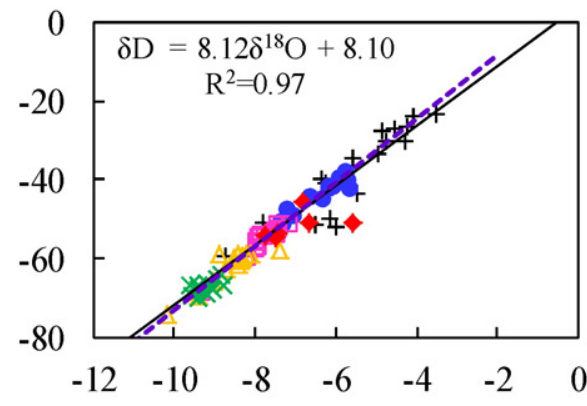

$\delta^{18} \mathrm{O}(\%)$

- Soil water $(0-20 \mathrm{~cm})$

Soil water $(50-90 \mathrm{~cm})$

+ Precipitation

* Irrigation water

------- Line fitting of $\delta \mathrm{D}$ and $\delta^{18} \mathrm{O}$ in soil water
2014
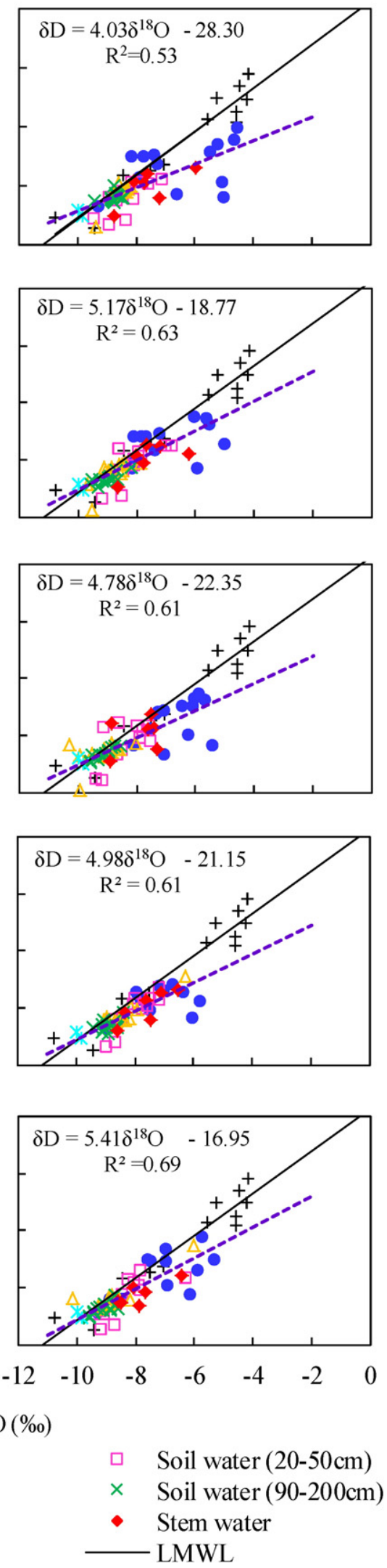

․ Soil water $(20-50 \mathrm{~cm})$

$\times \quad$ Soil water $(90-200 \mathrm{~cm})$ LMWL 
intermediate soil layer $(20-90 \mathrm{~cm})$ varied greatly. This layer was divided into $20-50 \mathrm{~cm}$ and $50-90 \mathrm{~cm}$ levels because of the larger changes of soil moisture and more distributed roots in the former layer. The isotopic composition and moisture levels in the deep soil profile $(90-200 \mathrm{~cm})$ were relatively uniform but there were few roots in this profile. Consequently, the $2-\mathrm{m}$ soil profile was divided into four layers of $0-20,20-50,50-90$, and $90-200 \mathrm{~cm}$.

The input data of the MixSIAR model were the measured dual isotope values ( $\delta \mathrm{D}$ and $\delta^{18} \mathrm{O}$ ) of stem water and soil water at different layers, and mean isotope discrimination values for each soil water source with standard error. The discrimination values were set to zero for both $\delta \mathrm{D}$ and $\delta^{18} \mathrm{O}$, mainly because there is no isotope fractionation during plant water uptake (Dawson and Ehleringer, 1991; Ehleringer and Dawson, 1992). Individual effects as a random occurrence were included in all analyses. The Markov Chain Monte Carlo parameter was set to "long" run length. The error options of "residual error" and "process error" were specified in the model. Trace plots and the diagnostic tests Gelman-Rubin, Heidelberger-Welch, and Geweke were used to determine whether the model converged or not. The estimated median (50\% quantiles) proportion (the median source contribution value for each water source) was analyzed for comparisons.

\section{Results}

\subsection{Isotopic composition of water}

$\delta^{18} \mathrm{O}$ in precipitation ranged from -8.72 to $-3.49 \%$, with mean value of $-5.64 \%$ and standard deviation (SD) of $1.39 \%$, whereas $\delta \mathrm{D}$ ranged from -59.47 to $-23.26 \%$, with a mean value of $-38.72 \%$ o and SD of $11.58 \%$ in the 2013 season (Fig. 2 and Table 3). For the 2014 season, $\delta^{18} \mathrm{O}$ in precipitation ranged from -10.74 to $-4.17 \%$, with a mean value of $-6.33 \%$ and SD of $2.25 \%$, whereas $\delta \mathrm{D}$ ranged from -74.66 to $-22.01 \%$, with a mean value of $-44.10 \%$ and SD of $17.43 \%$. The local meteoric water line (LMWL) was established as $\delta \mathrm{D}=7.61 \delta^{18} \mathrm{O}+4.20$ and $\delta \mathrm{D}=7.42 \delta^{18} \mathrm{O}+2.86$ in the 2013 and 2014 seasons, respectively. The slopes of the LMWL were lower than that of the global meteoric water line (GMWL), expressed as $\delta \mathrm{D}=$
$8 \delta^{18} \mathrm{O}+10$ (Craig, 1961). The LMWL slopes were also smaller than the slope of $\delta \mathrm{D}=7.94 \delta^{18} \mathrm{O}+3.92$ (Liu et al., 2014), based on the data between 2005 and 2010 collected at the Beijing station in the Chinese Network of Isotopes in Precipitation (CHNIP). The smaller slopes of the LMWL in this study were ascribed to the fast evaporation of the falling raindrops, especially in the dry year of 2014.

The $\delta^{18} \mathrm{O}$ in soil water ranged from -11.34 to $-4.32 \%$, with mean value of $-8.08 \%$ and $S D$ of $0.61 \%$, whereas $\delta$ D ranged from -77.26 to $-32.06 \%$, with a mean value of $-57.69 \%$ and SD of $4.06 \%$ in 2013 (Table 3). The range of $\delta^{18} \mathrm{O}$ in soil water was between -10.79 and $-3.12 \%$, with a mean value of $-8.31 \%$ and SD of $0.81 \%$, whereas $\delta \mathrm{D}$ ranged from -79.55 to $-36.16 \%$, with a mean value of $-62.20 \%$ and SD of $5.39 \%$ in 2014 (Table 3). Most isotopes of soil water fell on the LMWL in 2013 as evident from Fig. 2. However, stable isotopes of soil water were scattered and the slopes of soil water $\delta \mathrm{D}-\delta^{18} \mathrm{O}$ relationship (4.03-5.41) were lower than those of the LMWL in 2014 (7.42) (Fig. 2), which indicated a strong evaporation effect on soil water.

Soil water isotopes were enriched in topsoil and depleted with depth (Fig. 2). $\delta \mathrm{D}$ and $\delta^{18} \mathrm{O}$ values of soil water in the $90-200 \mathrm{~cm}$ layer were uniform with an average of $9.02 \%$ for $\delta^{18} \mathrm{O}$ and $65.67 \%$ for $\delta \mathrm{D}$. These values were similar to those of irrigation water (an average of $9.93 \%$ for $\delta^{18} \mathrm{O}$ and $69.32 \%$ for $\delta \mathrm{D}$ ). The soil water isotopes of the $0 \mathrm{~N}$ treatment were more enriched than those of the other treatments, especially in the upper layer of $0-20 \mathrm{~cm}$ during the two seasons studied (Fig. 2).

The $\delta \mathrm{D}$ and $\delta{ }^{18} \mathrm{O}$ of stem water ranged from -43.92 to $-70.47 \%$ and -5.57 to $-8.92 \%$, respectively (Table 3 ), which fell near the fitting line of soil water $\delta \mathrm{D}-\delta^{18} \mathrm{O}$ relationship (as shown in Fig. 2). The values of stem water isotopes were primarily between those of soil water in the $0-20 \mathrm{~cm}$ and $20-50 \mathrm{~cm}$ layers (Fig. 2). This result indicated that the principal sources of stem water were from soil water in the upper layers $(<50 \mathrm{~cm})$ for summer maize. Stem water $\delta \mathrm{D}$ and $\delta^{18} \mathrm{O}$ was notably different between 2013 and 2014 seasons (Fig. 2). The mean value of $\delta$ D was $-51.66 \%$ and $-60.27 \%$ in 2013 and 2014, respectively, and the mean value of $\delta^{18} \mathrm{O}$ was $-7.01 \%$ and $-7.71 \%$ in the same years, respectively.

Table 3

General characteristics of isotopic compositions in water samples across all sampling times.

\begin{tabular}{|c|c|c|c|c|c|c|c|c|c|c|}
\hline & \multirow[t]{2}{*}{ Type } & \multirow[t]{2}{*}{ Depth $(\mathrm{cm})$} & \multicolumn{4}{|l|}{$\delta^{18} \mathrm{O}(\%)$} & \multicolumn{4}{|l|}{$\delta \mathrm{D}(\%)$} \\
\hline & & & Max. & Min. & Mean & SD & Max. & Min. & Mean & SD \\
\hline \multirow[t]{12}{*}{2013} & Precipitation & & -3.49 & -8.72 & -5.64 & 1.39 & -23.26 & -59.47 & -38.72 & 11.58 \\
\hline & Soil water & 10 & -4.32 & -7.96 & -6.10 & 0.83 & -32.06 & -56.65 & -41.67 & 6.22 \\
\hline & & 20 & -5.24 & -8.41 & -6.80 & 0.66 & -33.70 & -58.74 & -45.96 & 5.39 \\
\hline & & 30 & -5.75 & -8.72 & -7.19 & 0.70 & -39.95 & -63.84 & -49.86 & 5.56 \\
\hline & & 50 & -6.71 & -9.94 & -7.94 & 0.52 & -48.82 & -72.53 & -56.01 & 4.26 \\
\hline & & 70 & -7.46 & -10.43 & -8.62 & 0.53 & -54.92 & -77.26 & -61.97 & 4.29 \\
\hline & & 90 & -7.08 & -11.01 & -8.94 & 0.59 & -59.01 & -75.19 & -65.15 & 3.46 \\
\hline & & 110 & -7.88 & -11.34 & -9.30 & 0.53 & -62.84 & -75.70 & -67.85 & 2.72 \\
\hline & & 150 & -6.75 & -10.69 & -9.23 & 0.57 & -61.93 & -72.38 & -68.02 & 2.38 \\
\hline & & 200 & -6.22 & -10.22 & -8.59 & 0.52 & -54.09 & -67.80 & -62.76 & 2.24 \\
\hline & & Total & -4.32 & -11.34 & -8.08 & 0.61 & -32.06 & -77.26 & -57.69 & 4.06 \\
\hline & Stem water & & -5.57 & -7.96 & -7.01 & 0.58 & -43.92 & -56.55 & -51.66 & 3.29 \\
\hline \multirow[t]{13}{*}{2014} & Precipitation & & -4.17 & -10.74 & -6.33 & 2.25 & -22.01 & -74.66 & -44.10 & 17.43 \\
\hline & Soil water & 10 & -3.12 & -9.52 & -6.51 & 1.62 & -36.16 & -70.36 & -52.82 & 8.15 \\
\hline & & 20 & -5.43 & -9.36 & -7.42 & 0.97 & -41.57 & -68.97 & -56.73 & 7.35 \\
\hline & & 30 & -5.65 & -9.65 & -8.03 & 0.86 & -49.58 & -75.87 & -60.47 & 7.41 \\
\hline & & 50 & -6.36 & -9.96 & -8.47 & 0.70 & -55.85 & -78.22 & -64.11 & 5.96 \\
\hline & & 70 & -4.56 & -10.56 & -8.63 & 0.93 & -38.08 & -79.20 & -63.37 & 5.85 \\
\hline & & 90 & -6.06 & -10.53 & -8.76 & 0.63 & -44.99 & -79.55 & -63.93 & 4.56 \\
\hline & & 110 & -6.81 & -9.86 & -8.83 & 0.55 & -49.92 & -76.83 & -65.14 & 3.41 \\
\hline & & 150 & -8.37 & -10.79 & -9.31 & 0.54 & -60.18 & -73.65 & -68.16 & 2.99 \\
\hline & & 200 & -7.50 & -9.84 & -8.83 & 0.49 & -59.27 & -71.68 & -65.07 & 2.86 \\
\hline & & Total & -3.12 & -10.79 & -8.31 & 0.81 & -36.16 & -79.55 & -62.20 & 5.39 \\
\hline & Irrigation water & & -9.85 & -10.01 & -9.93 & 0.11 & -68.18 & -70.46 & -69.32 & 1.61 \\
\hline & Stem water & & -5.97 & -8.92 & -7.71 & 0.77 & -52.53 & -70.47 & -60.27 & 5.18 \\
\hline
\end{tabular}




\subsection{Seasonal variation in depth of water uptake}

The direct inference method was used to determine the potential water uptake depth of summer maize (Brunel et al., 1997). The principle of this approach was to detect the depth at which the isotopic composition of soil water matched that of the stem water (Brunel et al., 1997). The variation of the isotopic composition of soil water in the $2 \mathrm{~m}$ profile during 2013 and 2014 is shown in Figs. 3 and 4. The vertical dotted line represents the isotopic composition of stem water sampled on the same date with soil water.

The isotopes of the stem and soil water overall matched at the depth of 10-20 cm before the tasseling stage in 2013 (Fig. 3). The predominant water uptake depth occurred at $30-50 \mathrm{~cm}$ from the tasselling to harvest stages. The maximal water uptake depth during the 2013 season occurred at the tasseling stage with $50-70 \mathrm{~cm}$ for the $1.5 \mathrm{~N}$ treatment and $30-50 \mathrm{~cm}$ for the other treatments. The isotopic matching depth

Seedling Jointing Tasseling Milk Dough Harvest

$\delta \mathrm{D}(\%)$

(a)

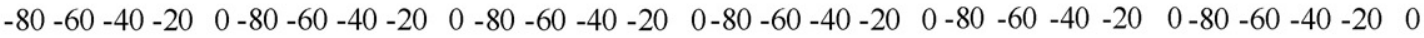
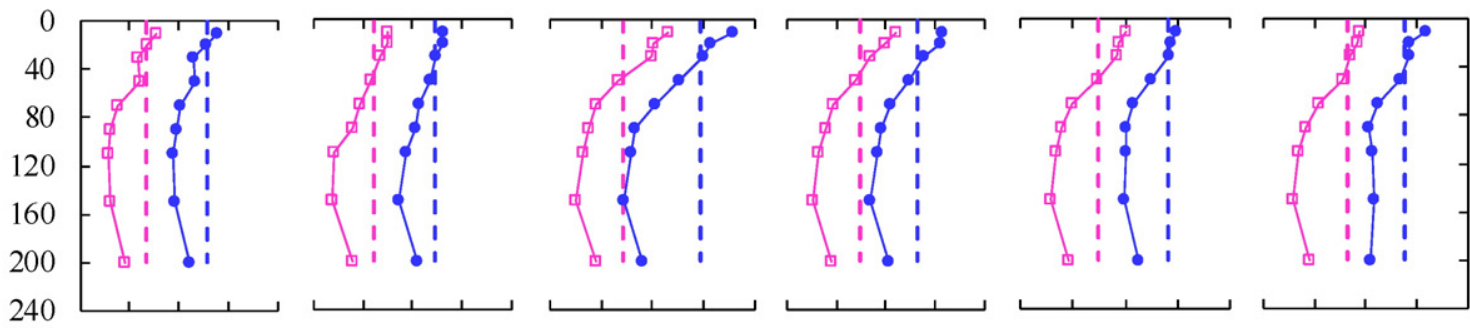

(b)

(c)
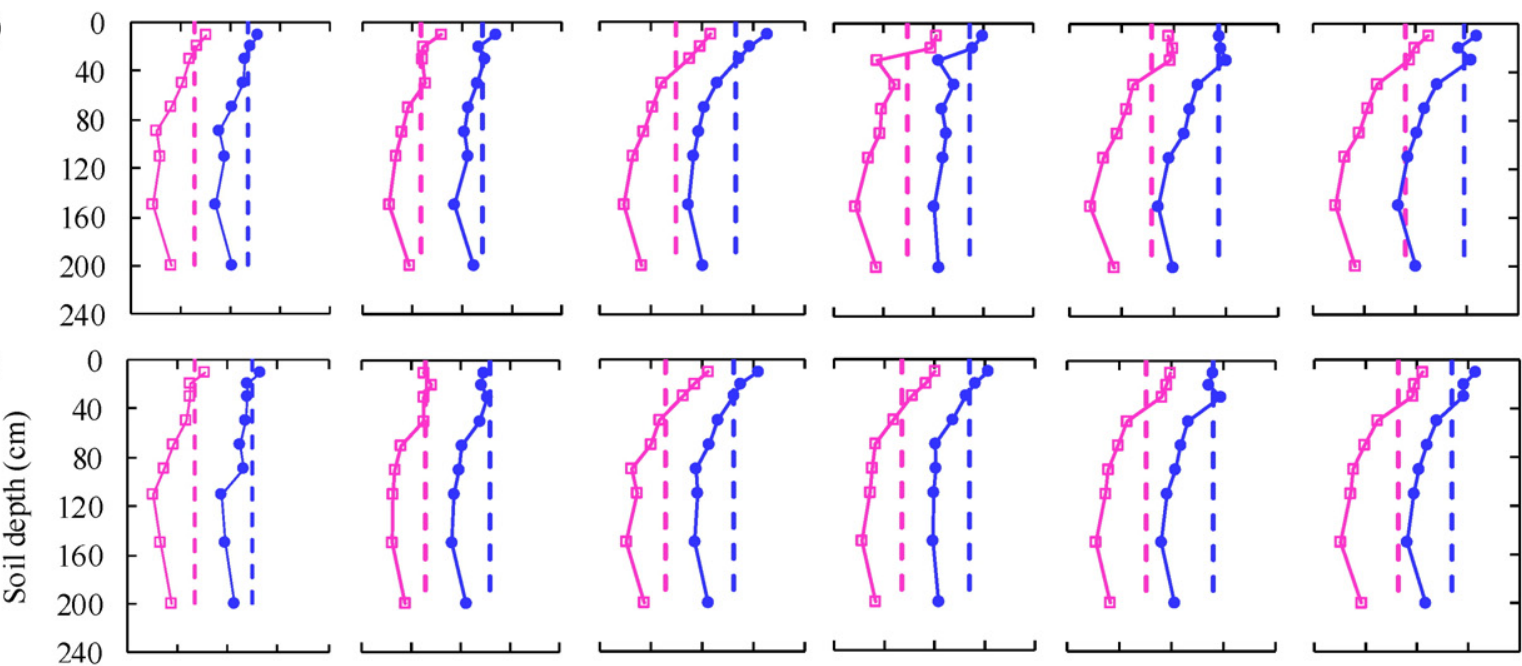

(d)
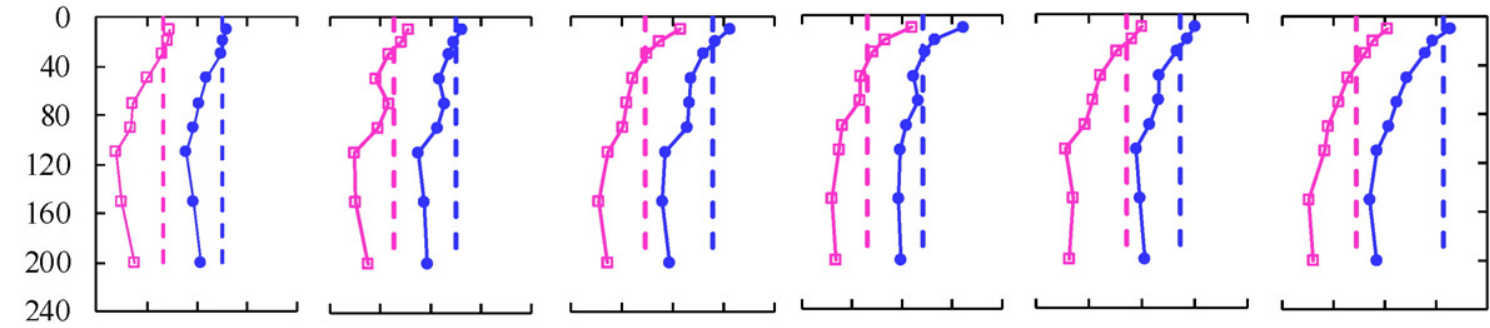

(e)
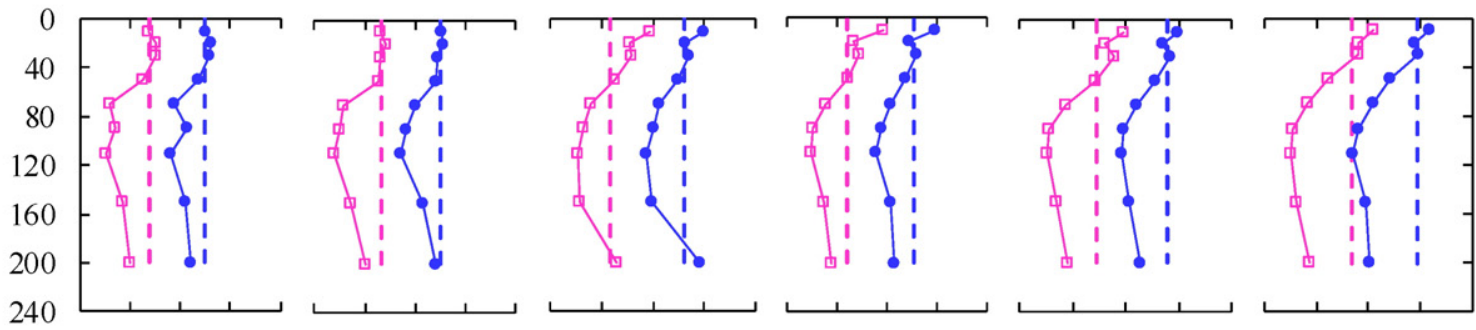

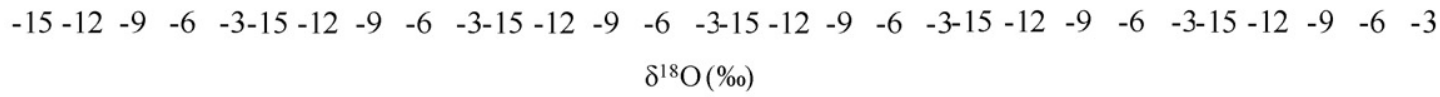

$\square-$ Soil water $(\delta \mathrm{D})---$ Stem water $(\delta \mathrm{D}) \longrightarrow$ Soil water $\left(\delta^{18} \mathrm{O}\right)---$ Stem water $\left(\delta^{18} \mathrm{O}\right)$ 
of soil water with stem water in 2014 differed greatly from that in 2013 since tasseling stage (Fig. 4). Moreover, there were notable differences among the water uptake depths of the five treatments in 2014. At the tasseling stage, the main water uptake depth stayed at $10-20 \mathrm{~cm}$ for all treatments. The depth changed to $30-110 \mathrm{~cm}$ at the milk stage for all treatments and the maximal value occurred at the $1.5 \mathrm{~N}$ treatment with $90-110 \mathrm{~cm}$. The water uptake depth returned to $20-30 \mathrm{~cm}$ and
$30-50 \mathrm{~cm}$ between the dough and harvest stages for most treatments. Nevertheless, it remained at 50-70 $\mathrm{cm}$ under the $1.0 \mathrm{~N}$ treatment.

\subsection{Proportional contribution of soil water at different depths}

The proportional contribution of soil water at different depths to summer maize was quantified by the MixSIAR model. The average

$\begin{array}{llll}\text { Seedling Jointing } & \text { Tasseling } & \text { Milk } & \text { Dough }(\%)\end{array}$

(a)

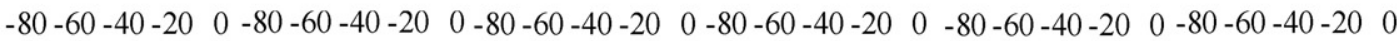
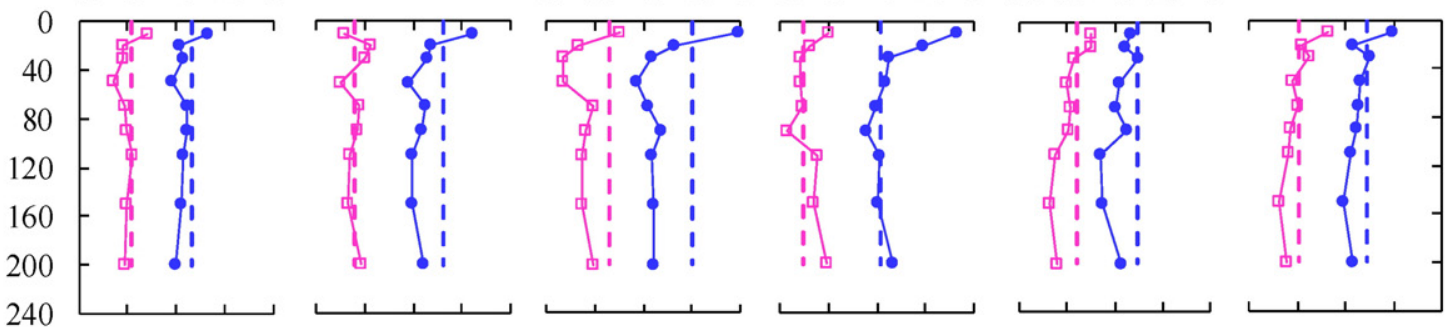

(b)
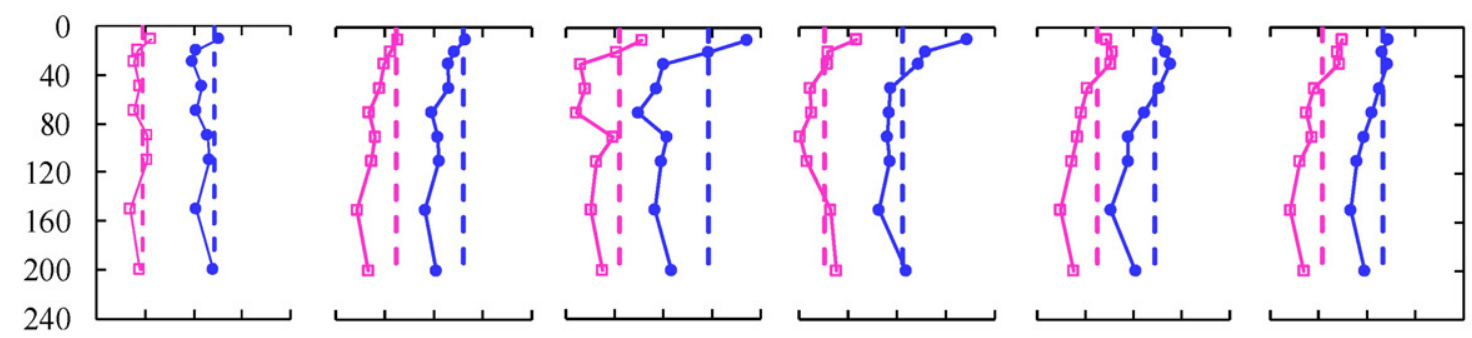

(c)
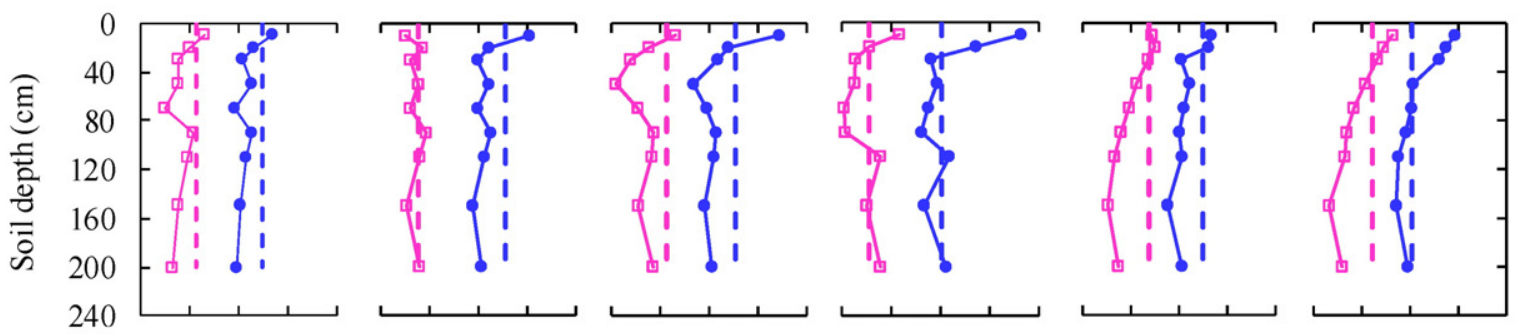

(d)
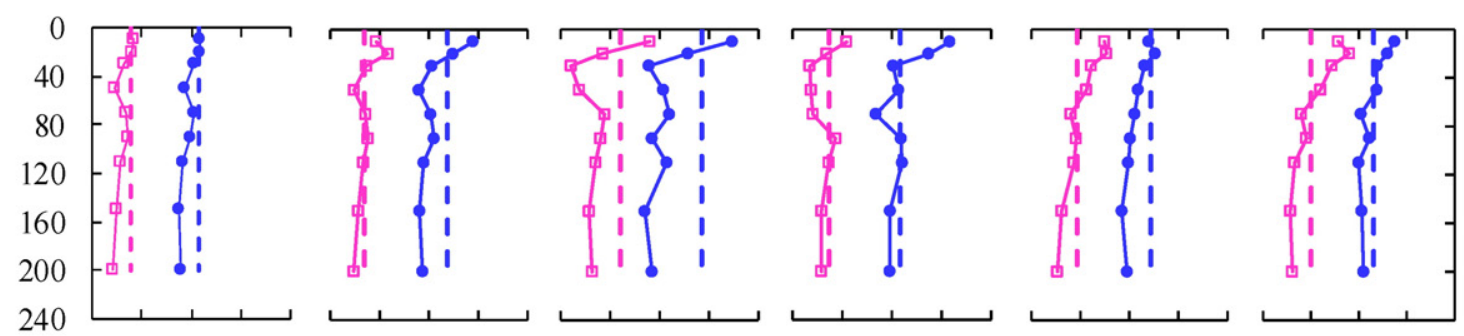

(e)
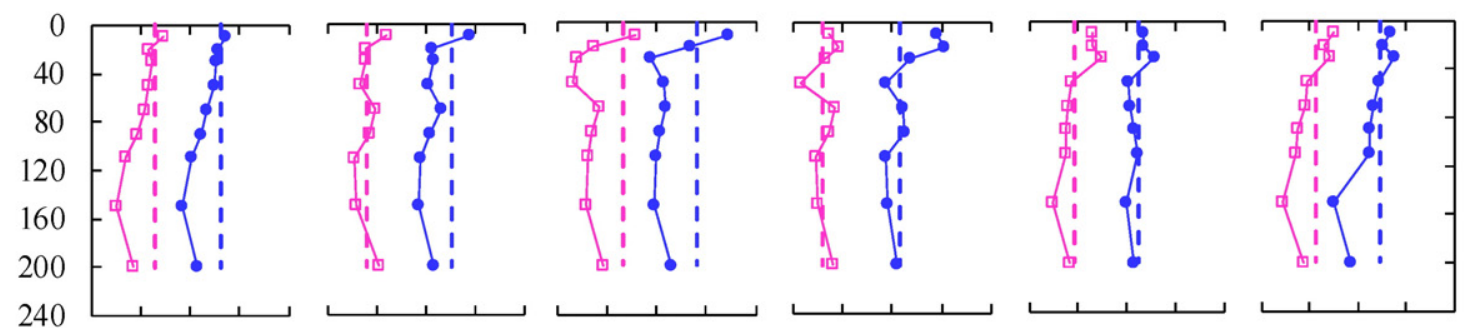

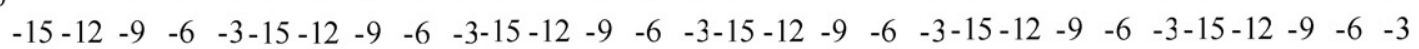

$\delta^{18} \mathrm{O}(\%)$

$\longrightarrow$ Soil water $(\delta \mathrm{D})---$ Stem water $(\delta \mathrm{D}) \longrightarrow$ Soil water $\left(\delta^{18} \mathrm{O}\right)---$ Stem water $\left(\delta^{18} \mathrm{O}\right)$ 
contribution of soil water in the $0-20,20-50,50-90$, and $90-200 \mathrm{~cm}$ layers was $47.2 \%, 24.9 \%, 15.2 \%$, and $12.8 \%$, respectively (Table 4 ). Summer maize mainly used soil water from 0 to $20 \mathrm{~cm}$ depth at the seeding (67.7\%), jointing (60.5\%), tasseling (47.5\%), dough (41.4\%), and harvest (43.9\%) stages, and from the $20-50 \mathrm{~cm}$ depth at the milk stage (32.8\%). The contribution of soil water in the $50-200 \mathrm{~cm}$ layers increased from seedling to milk stages, and then it decreased through the remaining stages. The maximal contribution of soil water in the layers of $50-90 \mathrm{~cm}$ and $90-200 \mathrm{~cm}$ layers at the milk stage was $22.9 \%$ and $22.4 \%$, respectively.

There were pronounced differences in seasonal water uptake for summer maize between the 2013 and 2014 seasons (Fig. 5). The water uptake depth was concentrated in the $0-50 \mathrm{~cm}$ layer in the 2013 season, with the proportional contribution greater than $63.2 \%$ at each growth stage. In the 2014 season, the dominant water uptake depth from seedling to tasseling stage was $0-20 \mathrm{~cm}$ with more than $62.6 \%$ contribution, whereas the contribution was only $10.7 \%$ in the $0-20 \mathrm{~cm}$ and $29.8 \%$ in the other three layers at the milk stage (Fig. 5). The dominant water uptake depth returned to $0-50 \mathrm{~cm}$ with more than $59.6 \%$ contribution at the dough and harvest stages in the 2014 season. The sharp increase of soil water contribution in the deep layers (50-200 cm) occurred at the tasseling stage in the 2013 season (from $17.0 \%$ to $36.8 \%$ ), whereas this increase was during the milk stage in the 2014 season (from $22.7 \%$ to $58.8 \%$ ). The soil water in the $50-200 \mathrm{~cm}$ layers in the 2014 season contributed more to summer maize (33.0\%) than it did in the 2013 season (22.9\%), particularly from the milk to harvest stages.
The water uptake patterns were notably different among the five treatments, especially in the $0-20$ and $20-50 \mathrm{~cm}$ layers (Table 4 and Fig. 5). The difference of soil water contribution in the $0-20 \mathrm{~cm}$ layer among the five treatments ranged from $6.0-58.5 \%$ with a mean value of $27.2 \%$, whereas that in the $20-50 \mathrm{~cm}$ layer ranged from $6.1-26.3 \%$ with a mean value of $16.2 \%$. The differences were also observed in the $50-90 \mathrm{~cm}$ layer at the milk stage, and 50-200 cm layers at the dough stage in 2014. For example, the $0 \mathrm{~N}$ treatment consumed up to $44.4 \%$ of soil water in the $50-90 \mathrm{~cm}$ depth at the milk stage, whereas the consumption value was merely $24.5 \%$ for the other four treatments. Compared with the $1.0 \mathrm{~N}$ treatment, the average proportional contribution of soil water for the other treatments was greater at $20-50 \mathrm{~cm}$ in 2013 and $0-20 \mathrm{~cm}$ in 2014 , especially at the dough stage. The contributions of soil water at the $20-50 \mathrm{~cm}$ layer in 2013 for the $0 \mathrm{~N}, 0.5 \mathrm{~N}, 0.75 \mathrm{~N}$, and $1.5 \mathrm{~N}$ treatments were $1.60-, 1.51-, 1.38-$, and 1.47 -fold that of the $1.0 \mathrm{~N}$ treatment, respectively. Similar values for the $0 \mathrm{~N}, 0.5 \mathrm{~N}, 0.75 \mathrm{~N}$, and $1.5 \mathrm{~N}$ treatments were $1.55-, 1.60-, 2.09-$, and 1.26 -fold at the $0-$ $20 \mathrm{~cm}$ depth in 2014, respectively.

\section{Discussion}

\subsection{Comparison of the direct inference method and MixSIAR model}

In general, the water uptake depth indicated by the direct inference method was consistent with that estimated by the MixSIAR model. The direct inference method was limited in that it could only give the main water uptake depth of summer maize. In addition, the inferred results

Table 4

Proportions of soil water contributions to summer maize at different stages.

\begin{tabular}{|c|c|c|c|c|c|c|c|c|}
\hline Season & Treatment & Layer $(\mathrm{cm})$ & Seedling & Jointing & Tasseling & milk & Dough & Harvest \\
\hline \multirow[t]{20}{*}{2013} & \multirow[t]{4}{*}{ ON } & $0-20$ & 74.2 & 33.9 & 24.5 & 28.2 & 34.9 & 46.5 \\
\hline & & $20-50$ & 15.3 & 41.9 & 34.6 & 42.6 & 31.2 & 38.3 \\
\hline & & $50-90$ & 5.4 & 14.4 & 22.5 & 14.8 & 18.3 & 8.6 \\
\hline & & $90-200$ & 5.1 & 9.7 & 18.4 & 14.4 & 15.6 & 6.5 \\
\hline & \multirow[t]{4}{*}{$0.5 \mathrm{~N}$} & $0-20$ & 71.2 & 33.5 & 32.6 & 52.5 & 41.6 & 64.5 \\
\hline & & $20-50$ & 16.0 & 40.5 & 39.8 & 16.9 & 37.8 & 19.5 \\
\hline & & $50-90$ & 6.8 & 14.8 & 16.7 & 17.2 & 12.1 & 9.2 \\
\hline & & $90-200$ & 6.1 & 11.3 & 10.9 & 13.4 & 8.5 & 6.8 \\
\hline & \multirow[t]{4}{*}{$0.75 \mathrm{~N}$} & $0-20$ & 73.7 & 72.4 & 24.3 & 29.2 & 44.1 & 47.7 \\
\hline & & $20-50$ & 16.7 & 21.8 & 35.7 & 41.1 & 31.2 & 31.9 \\
\hline & & $50-90$ & 5.4 & 2.9 & 20.3 & 15.2 & 13.0 & 10.4 \\
\hline & & $90-200$ & 4.2 & 2.8 & 19.6 & 14.5 & 11.8 & 10.0 \\
\hline & \multirow[t]{4}{*}{$1.0 \mathrm{~N}$} & $0-20$ & 75.4 & 58.8 & 40.5 & 27.2 & 75.8 & 34.9 \\
\hline & & $20-50$ & 14.6 & 16.6 & 31.4 & 36.4 & 11.5 & 37.6 \\
\hline & & $50-90$ & 5.5 & 16.5 & 16.3 & 21.5 & 7.4 & 15.5 \\
\hline & & $90-200$ & 4.5 & 8.0 & 11.9 & 15.0 & 5.4 & 12.0 \\
\hline & \multirow[t]{4}{*}{$1.5 \mathrm{~N}$} & $0-20$ & 69.4 & 74.7 & 21.5 & 29.3 & 37.2 & 66.8 \\
\hline & & $20-50$ & 25.9 & 20.7 & 31.3 & 38.5 & 37.6 & 18.1 \\
\hline & & 50-90 & 2.1 & 2.0 & 21.8 & 16.8 & 12.3 & 7.3 \\
\hline & & $90-200$ & 2.6 & 2.5 & 25.4 & 15.4 & 12.9 & 7.8 \\
\hline \multirow[t]{20}{*}{2014} & \multirow[t]{4}{*}{ ON } & $0-20$ & 56.5 & 67.0 & 72.7 & 5.4 & 40.1 & 41.3 \\
\hline & & $20-50$ & 10.2 & 10.7 & 8.0 & 22.0 & 23.8 & 30.3 \\
\hline & & $50-90$ & 21.1 & 12.5 & 9.8 & 44.4 & 22.7 & 16.9 \\
\hline & & $90-200$ & 12.2 & 9.8 & 9.5 & 28.2 & 13.5 & 11.5 \\
\hline & \multirow[t]{4}{*}{$0.5 \mathrm{~N}$} & $0-20$ & 64.7 & 74.6 & 47.9 & 13.6 & 35.7 & 46.3 \\
\hline & & $20-50$ & 8.0 & 11.4 & 18.4 & 34.6 & 36.2 & 38.7 \\
\hline & & $50-90$ & 16.5 & 7.1 & 15.0 & 25.2 & 16.0 & 9.0 \\
\hline & & $90-200$ & 10.8 & 7.0 & 18.7 & 26.6 & 12.2 & 6.0 \\
\hline & \multirow[t]{4}{*}{$0.75 \mathrm{~N}$} & $0-20$ & 70.5 & 75.7 & 57.4 & 12.6 & 68.9 & 36.5 \\
\hline & & $20-50$ & 10.9 & 8.3 & 13.5 & 29.6 & 11.9 & 38.6 \\
\hline & & $50-90$ & 9.7 & 8.6 & 14.7 & 24.7 & 10.1 & 14.7 \\
\hline & & $90-200$ & 8.9 & 7.4 & 14.4 & 33.1 & 9.1 & 10.1 \\
\hline & \multirow[t]{4}{*}{$1.0 \mathrm{~N}$} & $0-20$ & 58.3 & 53.8 & 80.3 & 15.3 & 10.4 & 21.0 \\
\hline & & $20-50$ & 14.3 & 14.4 & 6.5 & 30.1 & 19.2 & 32.7 \\
\hline & & $50-90$ & 18.8 & 18.1 & 6.9 & 25.1 & 40.5 & 24.8 \\
\hline & & $90-200$ & 8.6 & 13.7 & 6.2 & 29.5 & 29.8 & 21.5 \\
\hline & \multirow[t]{4}{*}{$1.5 \mathrm{~N}$} & $0-20$ & 63.0 & 61.0 & 73.5 & 6.7 & 24.9 & 33.4 \\
\hline & & $20-50$ & 20.1 & 12.9 & 8.1 & 36.0 & 26.9 & 34.3 \\
\hline & & $50-90$ & 10.4 & 15.6 & 9.5 & 23.8 & 23.3 & 21.3 \\
\hline & & $90-200$ & 6.5 & 10.5 & 8.9 & 33.5 & 25.0 & 11.1 \\
\hline
\end{tabular}


Seedling

Jointing

Tasseling

Milk

Dough

Harvest

Proportions of contribution (\%)

(a)

(b)

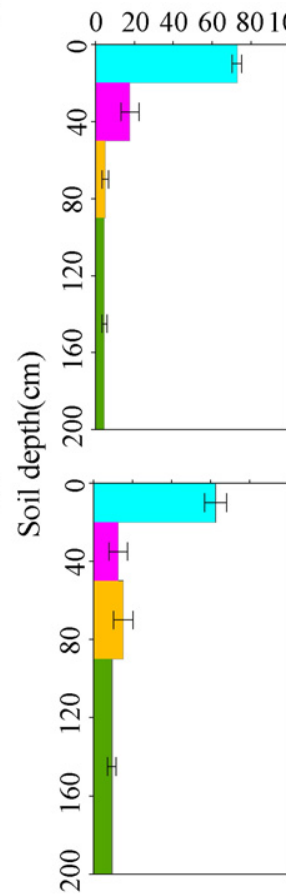

020406080100
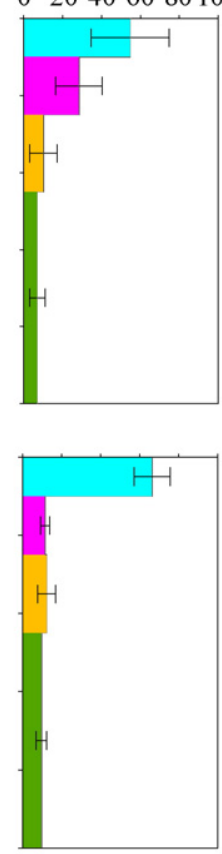

$0-20 \mathrm{~cm}$
$020406080100 \quad 0$
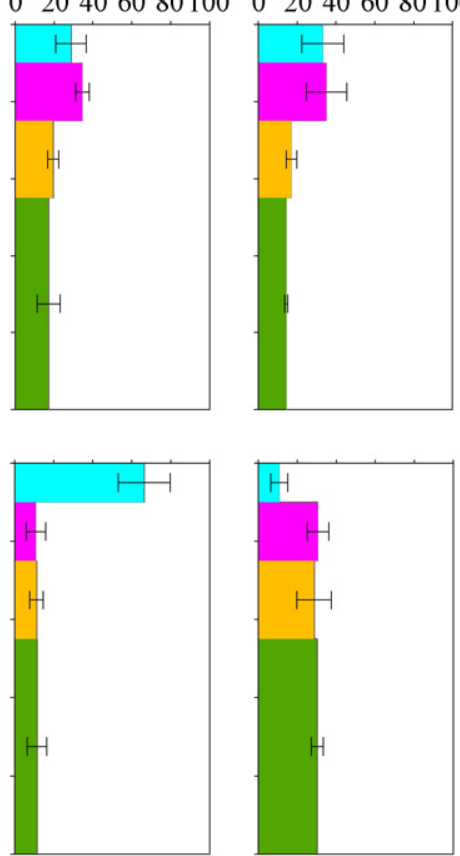

$20-50 \mathrm{~cm}$

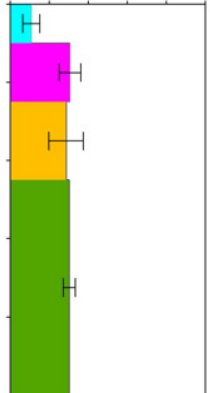

$50-90 \mathrm{~cm}$

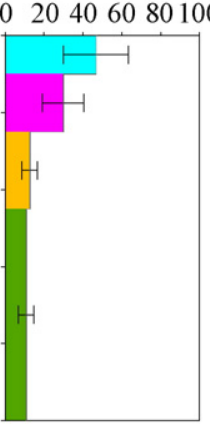

$0 \quad 20406080100$
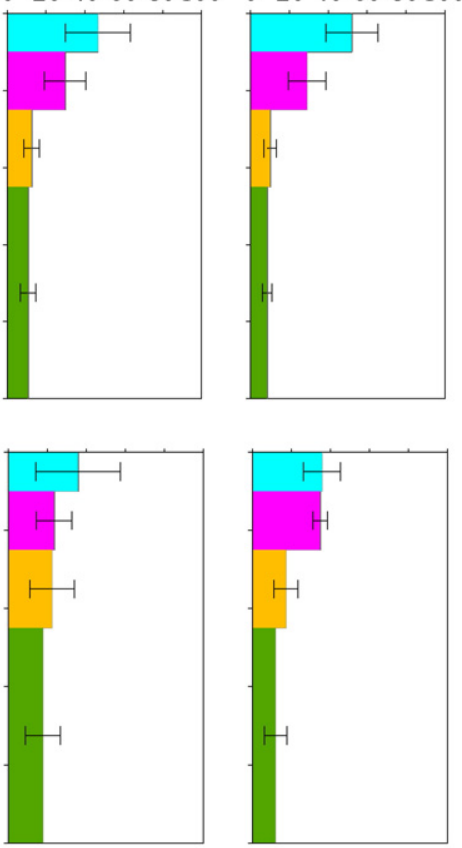

90-200 cm

Fig. 5. Proportions of soil water contributions to summer maize at each growth stage in: (a) 2013 season (b) 2014 season (mean \pm SD).

were at times uncertain. On one hand, the water uptake depth deduced by $\delta^{18} \mathrm{O}$ or $\delta \mathrm{D}$ was absolutely different. For instance, the main water uptake depth was determined to be $30-50 \mathrm{~cm}$, as observed from $\delta^{18} \mathrm{O}$, whereas the depth was $50-70 \mathrm{~cm}$ as suggested by $\delta \mathrm{D}$ for the $0.75 \mathrm{~N}$ treatment at the harvest stage in the 2014 season. On the other hand, there were a number of identical matching depths inferred by $\delta^{18} \mathrm{O}$ and $\delta \mathrm{D}$, including the $30-50 \mathrm{~cm}, 50-70 \mathrm{~cm}$, and $90-110 \mathrm{~cm}$ depths inferred at the milk stage in the 2014 season for the $1.5 \mathrm{~N}$ treatment.

The advantage of the MixSIAR model was that it could quantify the proportions of multi-source contributions using the dual stable isotopes $\delta^{18} \mathrm{O}$ and $\delta \mathrm{D}$. The model could also more reasonably characterize crop water use from soil depths. In contrast to the direct inference method that did not produce a certain result for the $0.75 \mathrm{~N}$ treatment at harvest in 2014, the contributions of the $0-20 \mathrm{~cm}, 20-50 \mathrm{~cm}, 50-90 \mathrm{~cm}$, and $90-200 \mathrm{~cm}$ layers were determined to be $36.5 \%, 38.6 \%, 14.7 \%$, and $10.1 \%$ by the MixSIAR model, respectively. The MixSIAR model also avoided the observation errors when there was more than one matching point between the isotopic compositions of stem water and soil water.

\subsection{Relationship between root distribution and water uptake}

Root distribution in the soil profile played a predominant role in water and nitrogen nutrient uptake for plant growth and yield formation. Summer maize has a fibrous root system that is divided into three categories: primary root, secondary root, and aerial root (Liu et al., 2009). Previous studies indicated that the vast majority of summer maize roots grow in the upper $40 \mathrm{~cm}$ of soil (Yi et al., 2009; Liu et al., 2009). Root biomass reaches its maximum at tasseling, pin silk, or milk stages (Yi et al., 2009), and the rooting depth development can be described as a sine function with time (Borg and Grimes, 1986).

In this experiment, root length density was maximal in the $0-10 \mathrm{~cm}$ layer with a mean value of $1.75 \mathrm{~cm} \mathrm{~cm}^{-3}$, and it decreased exponentially with depth. There was a significant positive correlation between the proportions of root length and soil water contribution to summer maize in each layer $(r=0.753, p<0.01)$ (Fig. 6). The average root length in the $0-20,20-50,50-90$, and $90-200 \mathrm{~cm}$ layers accounted for $51.7 \%$, $23.2 \%, 20.8 \%$, and $4.3 \%$, respectively, whereas $74.9 \%$ of the roots were concentrated in the topsoil of $0-50 \mathrm{~cm}$. Accordingly, the proportional contribution of soil water also decreased with depth, and that in the $0-50 \mathrm{~cm}$ layer accounted for $72.1 \%$ of total water uptake. The difference in root length density among the five treatments mainly occurred in the $0-20 \mathrm{~cm}$ layer with a SD of $0.14 \mathrm{~cm} \mathrm{~cm}^{-3}$, and the differences in soil water contribution among treatments also occurred in the same layer with a SD of $14.9 \%$.

\subsection{Relationship between soil moisture distribution and water uptake}

There was a distinct difference in rainfall distributions between 2013 and 2014 (Fig. 7), which resulted in seasonal variations of soil moisture distribution and root development patterns. The proportions of soil water used by the plants generally increased as the soil water content increased (Rose et al., 2003; Drake and Franks, 2003; Zhang et al., 2011b). The major changes in soil moisture during the 2013 season were in the $0-50 \mathrm{~cm}$ layer, which was in consistent with the major water uptake depth of this layer for more than $63.2 \%$ contribution indicated by the MixSIAR model. The soil water content was large with little variation in the $0-20 \mathrm{~cm}$ layer before the jointing stage because of 
plentiful rainfall, shallow primary roots for water uptake, and a low crop water requirement (Fig. 7). The soil moisture at 20-50 cm decreased from the jointing stage as secondary roots were dense and rapidly penetrated into deep layers, and the contribution of this layer increased from $17.7 \%$ to $28.3 \%$. In the 2013 season, the greatest reduction of soil moisture in the deep layers $(50-100 \mathrm{~cm})$ occurred at the tasseling stage (Fig. 7), when the sharp increase of soil water contribution also occurred at this stage (from $17.0 \%$ to $36.8 \%$ ). From the milk to harvest stages, the main reduction of soil moisture returned to $0-50 \mathrm{~cm}$, which was induced by the water uptake of the newly developed aerial roots. Soil moisture distribution among the five treatments in the 2013 season was different at $0-20 \mathrm{~cm}$ and $20-50 \mathrm{~cm}$ (as shown in Fig. 7), with the large difference of the soil water contribution in the 0-20 cm (from 6.0-41.2\%) and 20-50 cm (from 8.5-26.3\%) layers.

Seasonal drought in 2014 seriously restricted root development before the tasseling stage when soil moisture in the $0-20 \mathrm{~cm}$ layer was fully utilized. This result was consistent with the main water contribution of $0-20 \mathrm{~cm}$ (more than $62.6 \%$ ) calculated by the MixSIAR model. When soil moisture was close to the wilting point, supplemental irrigation of $80 \mathrm{~mm}$ was applied on 30th August to avoid limit on crop growth. Therefore, no soil moisture was lower than $10 \%$ even during

(a)

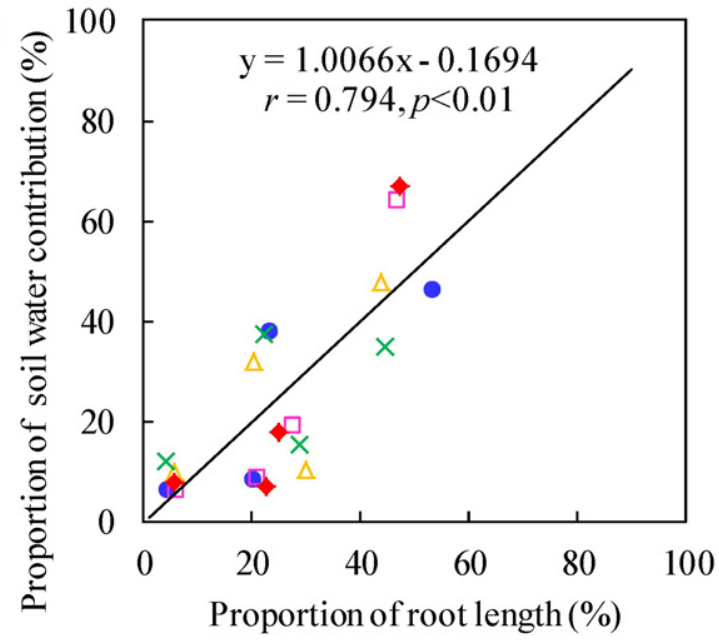

(b)

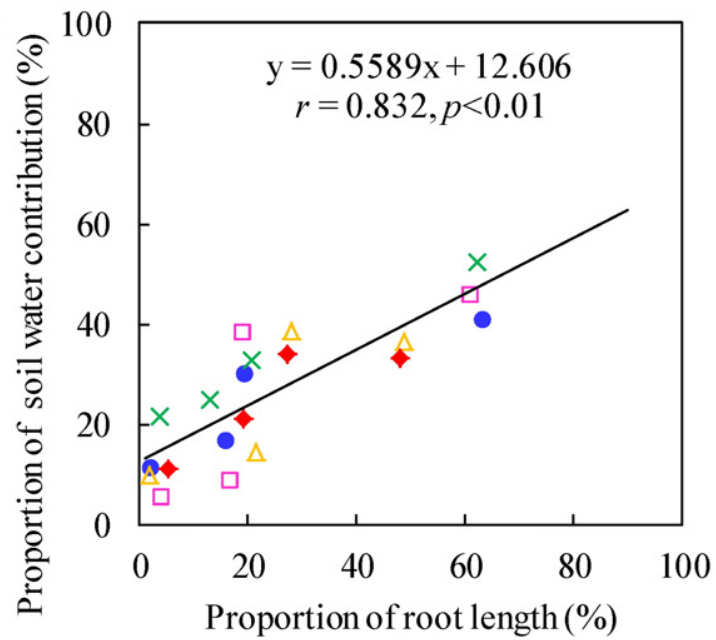
$\bullet 0 \mathrm{~N}$
$\square 0.5 \mathrm{~N}$
$\triangle 0.75 \mathrm{~N}$
$\times 1.0 \mathrm{~N}$
$\bullet 1.5 \mathrm{~N}$

Fig. 6. Relationship between soil water contribution to summer maize and proportions of root length in the: (a) 2013, and (b) 2014 season, respectively. the dry day at the tasseling stage (Fig. 7). Water at the deep soil depths (up to $150 \mathrm{~cm}$ ) was consumed as the crop grew into the milk stage in the 2014 season (Fig. 7). The average consumption of soil water was $15.7,32.6,28.9$, and $22.8 \mathrm{~mm}$ at the $0-20,20-50,50-90$, and $90-150 \mathrm{~cm}$ depths, respectively. This result confirmed the large proportions of soil water contribution to summer maize at the deeper layers (mean value of $29.8 \%$ ). The major difference in the soil moisture distribution among the five treatments occurred at the milk and dough stages in the 2014 season. At the milk stage, soil water content in the $50-90 \mathrm{~cm}$ layer with the $0 \mathrm{~N}$ treatment was significantly lower than that of the other treatments. At the dough stage, a large amount of soil water in the $0-50 \mathrm{~cm}$ layer was consumed for most treatments. The $0.75 \mathrm{~N}$ treatment had the greatest soil moisture reduction at $0-20 \mathrm{~cm}$, which was also consistent with the highest proportions of crop water use in this layer (68.9\%). The $1.0 \mathrm{~N}$ and $1.5 \mathrm{~N}$ treatments that had a greater level of fertilization consumed a large amount of soil water (23.8\%) from the $90-200 \mathrm{~cm}$ layer at the dough stage in the 2014 season. These results demonstrate that the changes of soil water distribution were consistent with the seasonal variation in water uptake patterns estimated by the MixSIAR model.

\subsection{Implications and further scopes of this study}

The application of nitrogen fertilizers has been one of the most important contributions to the increased production of summer maize in recent decades. Water is the critical carrier for nitrogen transport in SPAC. For summer maize, the amount of nitrogen uptake could reach $40-50 \%$ of the total nitrogen requirement after tasseling (Gallais et al., 2007). Main water uptake depth was or deeper than $0-50 \mathrm{~cm}$ in this study. When none fertilization ( $0 \mathrm{~N}$ treatment) was applied, roots tended to take water and nitrogen from deep soil layers of $50-90 \mathrm{~cm}$. As a result, the soil water content was significantly lower than that of the other treatments at the milk stage in 2014 season (Fig. 7). However, the proportion of root length density was small in the deep layer with ON treatment. Once large amount of fertilization supplied (such as $1.5 \mathrm{~N}$ treatment), the proportion of roots for nitrogen uptake was reduced even though the total root biomass enlarged (Robinson, 2001).

The appropriate fertilization supply could generate less but rational root distribution in the profile to improve the water and nitrogen use efficiencies. For example, root length in the $20-50 \mathrm{~cm}$ layer accounted for a large proportion $(27.2 \%)$ of the total root length under the $0.5 \mathrm{~N}$ treatment, which was half of the conventional nitrogen application rate (122.5 $\mathrm{kg} \mathrm{N} \mathrm{ha}^{-1}$ ) in the normal year (2013). The application of nitrogen advanced water uptake in the corresponding layer at a critical growth stage (39.8\% at tasseling stage) and increased the crop yield by $14.8 \%\left(14,790 \mathrm{~kg} \mathrm{ha}^{-1}\right)$, compared to the conventional practice $\left(12,880 \mathrm{~kg} \mathrm{ha}^{-1}\right)$. This optimal fertilization supply was similar to that of $120 \mathrm{~kg} \mathrm{~N} \mathrm{ha}^{-1}$ obtained by Ju et al. (2002). In the dry season (2014), slightly more fertilization ( $183.75 \mathrm{~kg} \mathrm{~N} \mathrm{ha}^{-1}$ ) was required to alleviate the negative effects of the water deficit with a yield increase of $8.0 \%$.

Nitrate, the main form of nitrogen, was more likely to transport into deep soil layers with water movement under irrigation or heavy rain event. Nitrate and root water uptake tended to be enhanced in these deep layers. For example, after irrigation of $80 \mathrm{~mm}$ and heavy rainfall, root water uptake at $90-200 \mathrm{~cm}$ was strong with $29.8 \%$ and $25.0 \%$ contribution under large fertilization supplies of $1.0 \mathrm{~N}$ and $1.5 \mathrm{~N}$, respectively, at the dough stage in 2014. However, excessive fertilization increases the risk of nitrate leaching into deep soil and polluting groundwater. Previous studies have demonstrated a logarithmic correlation between the amount of nitrogen application and nitrate leaching (Ju et al., 2009). Therefore, rational fertilization application is crucial for efficient utilization of water and fertilizer resources.

The seasonal water uptake patterns of summer maize estimated by the MixSIAR model varied with the fertilization applications and growth seasons. The evaluation using isotopic data presented a quantitative 
Days after sowing (d)

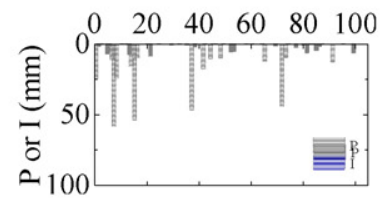

(a)

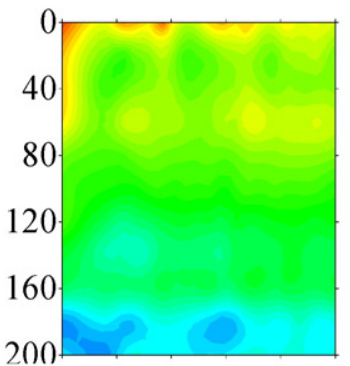

(b)

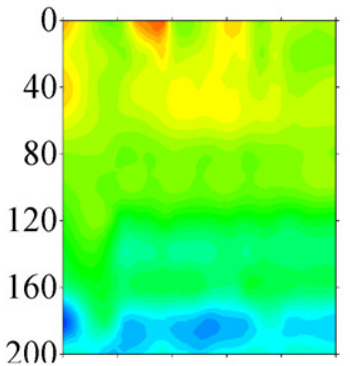

(c)

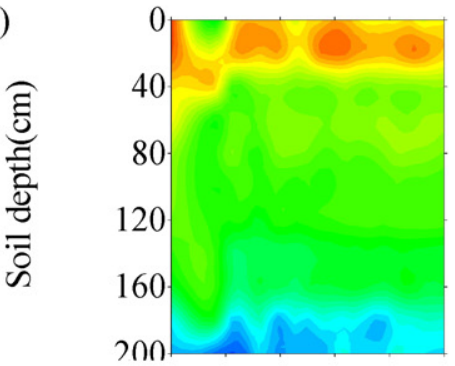

(d)

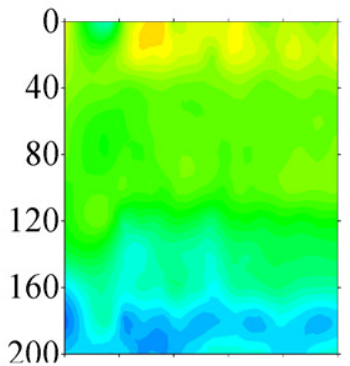

(e)

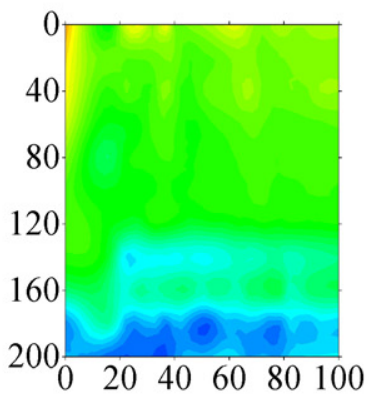

Days after sowing (d)
Days after sowing (d)
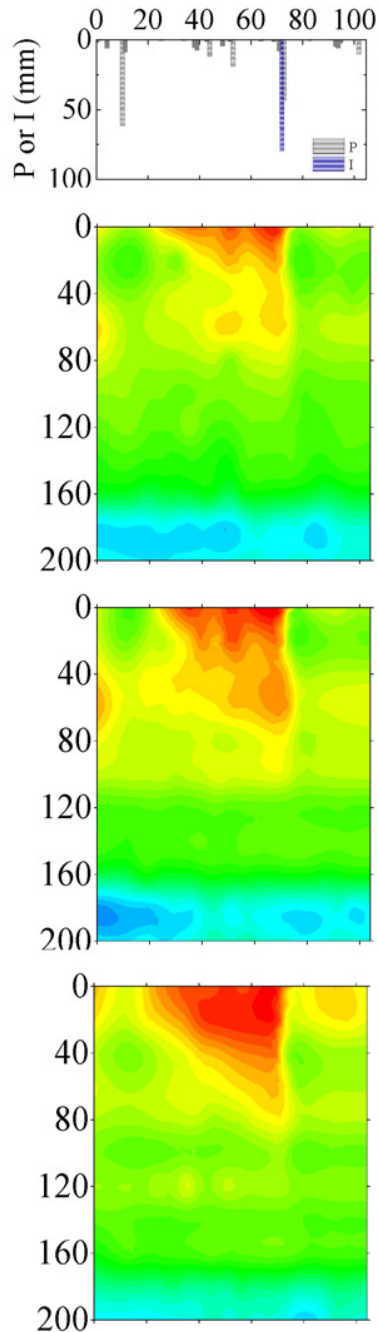

Soil water content

(Unit: $\mathrm{cm}^{3} \mathrm{~cm}^{-3}$ )

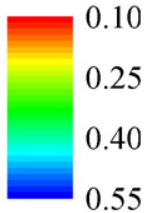

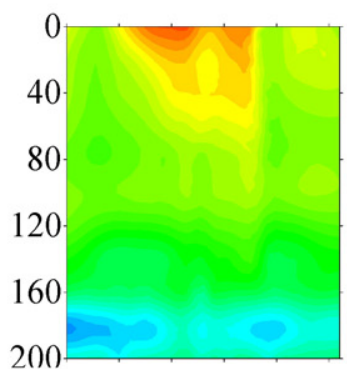

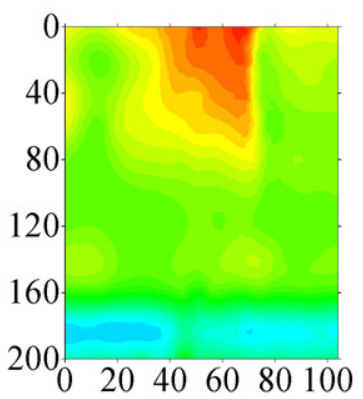

Days after sowing (d)

2014 
interpretation of crop water use from various soil depths. This method explicitly contributed to the field water cycle, and provided insights into exploring optimal water and nitrogen management practices. Nevertheless, further studies on soil water movement and nitrate leaching processes using stable isotope tracers are desirable for heavy rainfall or irrigation events. Moreover, the stable isotope technique can be coupled with water-energy balance measurements and model simulation to characterize crop water consumption and partition evapotranspiration. These studies provide an important scientific basis for reducing nitrogen leaching and improving water and nitrogen use efficiency.

\section{Conclusion}

In this study, the MixSIAR Bayesian mixing model coupled with D and ${ }^{18} \mathrm{O}$ dual stable isotopes technique was used to determine seasonal variations in water uptake of summer maize under different fertilization treatments during 2013-2014 in Beijing, China. The main water uptake depth was 0-20 cm (67.7\%), 0-20 cm (60.5\%), 0-20 cm (47.5\%), $20-50 \mathrm{~cm}$ (32.8\%), 0-20 cm (41.4\%), and 0-20 cm (43.9\%) at seeding, jointing, tasseling, milk, dough, and harvest stages, respectively. The average contribution of soil water in the $0-20,20-50,50-90$, and $90-200 \mathrm{~cm}$ layers was $47.2 \%, 24.9 \%, 15.2 \%$, and $12.8 \%$ during the experimental period, respectively. Throughout the normal year of 2013, soil water contribution in the upper soil layers $(0-50 \mathrm{~cm})$ was over $63.2 \%$, whereas seasonal drought promoted the contribution of soil water in deep layers $(50-200 \mathrm{~cm})$ in the dry year of 2014 . Various fertilization applications led to clear differences in the proportional contribution of soil water at $0-50 \mathrm{~cm}(6.0-58.5 \%)$ and $20-50 \mathrm{~cm}(6.1-26.3 \%)$. The differences were even observed in 50-90 cm layer at the milk stage and the $50-200 \mathrm{~cm}$ level at the dough stage during the dry season. The difference of quantitative contributions of soil water among treatments was closely related to root length and soil moisture distributions. This study provides a useful method for identifying crop water sources and the findings are of great significance for future fertilization and irrigation management.

\section{Acknowledgments}

This research was partially supported by the National Natural Science Foundation of China (Grant No. 41101029), the Key Project for the Strategic Science Plan in IGSNRR, CAS (Grant No. 2012ZD003), and Open Fund from State Key Laboratory of Soil and Sustainable Agriculture (Grant No. 0812201245). Sincere thanks go to Ningxia Sun. for collecting field data. We thank Pro. Yu Liu and Dr. Baozhong Zhang for their substantial supports on the field experiments. We thank the associate editor and anonymous reviewer for their comments to improve this manuscript.

\section{References}

Asbjornsen, H., Mora, G., Helmers, M.J., 2007. Variation in water uptake dynamics among contrasting agricultural and native plant communities in the Midwestern US. Agric. Ecosyst. Environ. 121, 343-356.

Barnes, C.J., Turner, J.V., 1998. Isotopic exchange in soil water. In: Kendall, C., McDonnell, J.J. (Eds.), Isotopic tracers in catchment hydrology. Elsevier, Amsterdam, pp. 137-163.

Borg, H., Grimes, D.W., 1986. Depth development of roots with time: an empirical description. Trans. ASAE 29, 194-197.

Brunel, J.P., Walker, G.R., Kennett-Smith, A.K., 1995. Field validation of isotopic procedures for determining sources of water used by plants in a semi-arid environment. J. Hydrol. 167, 351-368.

Brunel, J.P., Walker, G.R., Dighton, J.C., Monteny, B., 1997. Use of stable isotopes of water to determine the origin of water used by the vegetation and to partition evapotranspiration. A case study from HAPEX-Sahel. J. Hydrol. 188-189, 466-481.

Butler II, T.W., 2007. Application of multiple geochemical indicators, including the stable isotopes of water, to differentiate water quality evolution in a region influenced by various agricultural practices and domestic wastewater treatment and disposal. Sci. Total Environ. 388, 149-167.
Cai, J.B., Liu, Y., Xu, D., Paredes, P., Pereira, L.S., 2009. Simulation of the soil water balance of wheat using daily weather forecast messages to estimate the reference evapotranspiration. Hydrol. Earth Syst. Sci. 13, 1045-1059.

Craig, H., 1961. Isotopic variations in meteoric waters. Science 133, 1702-1703.

Darrouzet-Nardi, A., D'Antonio, C.M., Dawson, T.E., 2006. Depth of water acquisition by invading shrubs and resident herbs in a Sierra Nevada meadow. Plant Soil 285, 31-43.

Dawson, T.E., Ehleringer, J.R., 1991. Streamside trees that do not use stream water. Nature $350,335-337$.

Drake, P.L., Franks, P.J., 2003. Water resource partitioning stemxylem hydraulic properties and plant water use strategies in a seasonally dry riparian tropical rainforest. Oecologia 137, 321-329.

Ehleringer, J.R., Dawson, T.E., 1992. Water uptake by plants: perspectives from stable isotopes composition. Plant Cell Environ. 15, 1073-1082.

Erhardt, E.B., Bedrick, E.J., 2013. A Bayesian framework for stable isotope mixing models. Environ. Ecol. Stat. 20, 377-397.

Gallais, A., Coque, M., Gouis, J.L., Prioul, J.L., Hirel, B., Quilléré, I., 2007. Estimating proportions of nitrogen remobilization and of postsilking nitrogen uptake allocated to maize kernels by nitrogen-15 labeling. Crop Sci. 47, 685-691.

Gat, J.R., 1996. Oxygen and hydrogen isotopes in the hydrologic cycle. Annu. Rev. Earth Planet. Sci. 24, 225-262.

Ju, X.T., Liu, X.J., Zhang, F.S., 2002. Study on effect of nitrogen fertilizer and nitrogen balance in winter wheat and summer maize rotation system. Sci. Agric. Sin. 35, $1361-1368$ (in Chinese)

Ju, X.T., Xing, G.X., Chen, X.P., Zhang, S.L., Zhang, L.J., Liu, X.J., et al., 2009. Reducing environmental risk by improving $\mathrm{N}$ management in intensive Chinese agricultural systems. PNAS 106, 3041-3046.

Kang, S.Z., Shi, W.J., Zhang, J.H., 2000. An improved water-use efficiency for maize grown under regulated deficit irrigation. Field Crop Res. 67, 207-214.

Liu, C., 1997. Study on interface processes of water cycle in soil-plant-atmosphere continuum. Acta Geograph. Sin. 52, 366-374 (in Chinese).

Liu, J.M., An, S.Q., Liao, R.W., Ren, S.X., Liang, H., 2009. Temporal variation and spatial distribution of the root system of corn in a soil profile. Chinese J. Eco-Agric. 17, 517-521 (in Chinese).

Liu, J.R., Song, X.F., Yuan, G.F., Sun, X.M., Yang, L.H., 2014. Stable isotopic compositions of precipitation in China. Tellus B 66, 22567http://dx.doi.org/10.3402/tellusb.v66.22567.

Maduabuchi, C., Faye, S., Maloszewski, P., 2006. Isotope evidence of palaeorecharge and palaeoclimate in the deep confined aquifers of the Chad Basin, NE Nigeria. Sci. Total Environ. 370, 467-479.

McCole, A.A., Stern, L.A., 2007. Seasonal water use patterns of Juniperus ashei on the Edwards plateau, Texas, based on stable isotopes in water. J. Hydrol. 342, 238-248.

Moore, J.W., Semmens, B.X., 2008. Incorporating uncertainty and prior information into stable isotope mixing models. Ecol. Lett. 11, 1-11.

Parnell, A.C., Inger, R., Bearhop, S., Jackson, A.L., 2010. Source partitioning using stable isotopes: coping with too much variation. PLoS One 5, e9672. http://dx.doi.org/10.1371/ journal.pone.009672.

Philip, J.R., 1966. Plant water relations: some physical aspects. Annu. Rev. Plant Physiol 17, 245-268.

Phillips, D.L., Gregg, J.W., 2003. Source partitioning using stable isotopes: coping with too many sources. Oecologia 136, 261-269.

Popescu, R., Mimmo, T., Dinca, O.R., Capici, C., Costinel, D., Sandru, C., et al., 2015. Using stable isotopes in tracing contaminant sources in an industrial area: A case study on the hydrological basin of the Olt River, Romania. Sci. Total Environ. 533, 17-23.

Qi, Z., Helmers, M.J., Malone, R.W., Thorp, K.R., 2011. Simulating long-term impacts of winter rye cover crop on hydrologic cycling and nitrogen dynamics for a cornsoybean crop system (RZWQM-DSSAT). Trans. ASABE 54, 1575-1588.

Robinson, D., 2001. Root proliferation, nitrate inflow and their carbon costs during nitrogen capture by competing plants in patchy soil. Plant Soil 232, 41-50.

Rose, K.L., Graham, R.C., Parker, D.R., 2003. Water source utilization by Pinusjeffreyi and Arctostaphylos patula on thin soils over bedrock. Oecologia 134, 46-54.

Schwendenmann, L., Pendall, E., Sanchez-Bragado, R., Kunert, N., Hölscher, D., 2015. Tree water uptake in a tropical plantation varying in tree diversity: interspecific differences, seasonal shifts and complementarity. Ecohydrology 8, 1-12.

Snyder, K.A., Williams, D.G., 2000. Water sources used by riparian trees varies among stream types on the San Pedro River, Arizona. Agric. For. Meteorol. 105, 227-240.

Stock, B.C., Semmens, B.X., 2013. MixSIAR GUI User Manual, version 1.0. http://conserver. iugo-cafe.org/user/brice.semmens/MixSIAR.

Tilman, D., Kenneth, G.C., Pamela, A.M., Rosamond, N., Stephen, P., 2002. Agricultural sustainability and intensive production practices. Nature 418, 671-677.

Wang, X.P., Huang, G.H., 2008. Evaluation on the irrigation and fertilization management practices under the application of treated sewage water in Beijing, China. Agric. Water Manag. 95, 1011-1027.

Wang, F.X., Feng, S.Y., Hou, X.Y., Kang, S.Z., Han, J.J., 2009. Potato growth with and without plastic mulch in two typical regions of Northern China. Field Crop Res. 110, 123-129.

Wang, P., Song, X.F., Han, D.M., Zhang, Y.H., Liu, X., 2010. A study of root water uptake of crops indicated by hydrogen and oxygen stable isotopes: A case in Shanxi Province, China. Agric. Water Manag. 97, 475-482.

Wang, P., Song, X.F., Han, D.M., Zhang, Y.H., Zhang, B., 2012. Determination of evaporation, transpiration and deep percolation of summer corn and winter wheat after irrigation. Agric. Water Manag. 105, 32-37.

Ward, E.J., Semmens, B.X., Schindler, D.E., 2010. Including source uncertainty and prior information in the analysis of stable isotope mixing models. Environ. Sci. Technol. 44 4645-4650.

West, A.G., Patrickson, S.J., Ehleringer, J.R., 2006. Water extraction times for plant and soil materials used in stable isotope analysis. Rapid Commun. Mass Spectrom. 20, 1317-1321. 
Yang, B., Wen, X.F., Sun, X.M., 2015. Seasonal variations in depth of water uptake for a subtropical coniferous plantation subjected to drought in an East Asian monsoon region. Agric. For. Meteorol. 201, 218-228.

Yi, Z.X., Wang, P., Tu, N.M., 2009. Responses of roots distribution and nitrogen content of summer maize to nitrogen fertilization types and amounts. Plant Nutr. Fert. Sci. 21, 475-484.

Zhang, Y.C., Shen, Y.J., Sun, H.Y., Gates, J.B., 2011a. Evapotranspiration and its partitioning in an irrigated winter wheat field: a combined isotopic and micrometeorologic approach. J. Hydrol. 408, 203-211.
Zhang, C.Z., Zhang, J.B., Zhao, B.Z., Zhu, A.N., Zhang, H., Huang, P., et al., 2011b. Coupling a two-tip linear mixing model with a $\delta \mathrm{D}-\delta^{18} \mathrm{O}$ plot to determine water sources consumed by maize during different growth stages. Field Crop Res. 123, 196-205.

Zimmermann, U., Ehhalt, D., Munnich, K., 1967. Soil water movement and evapotranspiration: changes in the isotopic composition of the water. Proceedings of the IAEA Symposium on the Use of Isotopes in Hydrology. IAEA, Vienna, pp. 567-584. 